\title{
PEMANFAATAN LIMBAH PADAT PENGOLAHAN RUMPUT LAUT Gracilaria sp. UNTUK PEMBUATAN PAPAN PARTIKEL
}

\author{
Bakti Berlyanto Sedayu*), Tri Nugroho Widianto*), Jamal Basmal*), dan Bagus Sediadi Bandol Utomo*)
}

\begin{abstract}
ABSTRAK
Limbah padat dari industri pengolahan rumput laut hingga saat ini belum termanfaatkan dan pembuangan akhirnya menjadi masalah bagi perusahaan. Salah satu alternatif untuk memanfaatkannya adalah dengan memproses limbah padat tersebut menjadi papan partikel. Pada penelitian ini limbah padat dari industri pengolahan rumput laut Gracilaria sp. dicampur dengan bahan pengikat polietilen (PE) pada suhu ruang dengan perbandingan bobot 1:1, kemudian dihomogenkan. Pembuatan papan partikel dilakukan dengan teknik pengempaan panas dengan cetakan $30 \times 30 \times 2,5 \mathrm{~cm}^{3}$. Pengempaan dilakukan pada tekanan $10 \mathrm{~kg} / \mathrm{cm}^{2}$, suhu $150^{\circ} \mathrm{C}$, dengan variasi lama pengempaan 3,5 , dan 7 menit. Hasil penelitian menunjukkan bahwa papan partikel yang dibuat dari bahan limbah padat pengolahan rumput laut Gracilaria sp. dengan bahan pengikat PE memiliki sifat mekanis dengan kekuatan rendah sampai dengan sedang dengan nilai keteguhan patah (MOR) $58,88-96,78 \mathrm{~kg} / \mathrm{cm}^{2}$ dan keteguhan lentur (MOE) 2.425$6.326 \mathrm{~kg} / \mathrm{cm}^{2}$. Sifat fisik penyerapan air papan partikel yang dihasilkan sangat baik yaitu kurang dari $12 \%$, dengan daya serap air, pengembangan tebal, dan pengembangan linear masingmasing $2,43-3,92 \%, 0,00-1,17 \%$, dan $0,09-1,37 \%$. Nilai keteguhan rekat mencapai $6,41-7,39$ $\mathrm{kg} / \mathrm{cm}^{2}$, dan uji rayap $1,55-6,79 \%$. Secara keseluruhan, papan partikel terbaik dihasilkan dari perlakuan pengempaan panas selama 3 menit.
\end{abstract}

\section{ABSTRACT: Utilization of solid waste from Gracilaria sp. processing for particle board. By: Bakti Berlyanto Sedayu, Tri Nugroho Widianto, Jamal Basmal, and Bagus Sediadi Bandol Utomo}

Solid waste from Gracilaria sp. processing industries, so far has not been utilized, instead the waste became a problem to the company. One of the alternatives to utilize the solid waste from Gracillaria sp. processing is to process it to a particle board. In this experiment, solid waste from Gracilaria sp. processing industry was mixed with a binder agent (poly-ethylene/PE), at ratio of $1: 1$ by weight, then homogenized. The particle board processing was conducted by applying heat-pressing technique in a square templates of $30 \times 30 \times 2.5 \mathrm{~cm}^{3}$. The pressure applied was 10 $\mathrm{kg} / \mathrm{cm}^{2}$, at $150^{\circ} \mathrm{C}$ for 3,5 , and 7 minutes. The results showed that in general the particle boards produced by mixing of Gracilaria sp. processing waste and PE have mechanical properties of low to medium strength, with modulus of rupture (MOR) of $58.88-96.78 \mathrm{~kg} / \mathrm{cm}^{2}$, and modulus of elasticity (MOE) of 2,425-6,326 kg/ $\mathrm{cm}^{2}$. The physical properties of the particle board namely water adsorption were below $12 \%$, thickness swelling, and linear swelling were $2.43-3.92 \%$, $0.00-1.17 \%$, and $0.09-1.37 \%$, respectively, and can be classified as excellent. Internal bond strength were $6.41-7.39 \mathrm{~kg} / \mathrm{cm}^{2}$, and termite resistance were $1.55-6.79 \%$. In general, the best particle board was produced by hot pressing for 3 minutes.

KEYWORDS: $\quad$ solid waste, Gracilaria sp., particle board

\section{PENDAHULUAN}

Produksi pengolahan rumput laut menghasilkan jumlah limbah yang sangat besar baik berupa limbah cair maupun limbah padat. Salah satu limbah yang dihasilkan oleh industri pengolahan rumput laut yaitu limbah padat hasil pengolahan produk agar. Berdasarkan data penelitian oleh Pusat Riset Pengolahan Produk dan Sosial Ekonomi Kelautan dan Perikanan Tahun 2002-2003, jumlah limbah padat yang dihasilkan pada pengolahan agar berkisar $70-85 \%$ (Basmal et al., 2003). Sejak berkembangnya industri pengolahan agar sampai dengan saat ini, belum ada kegiatan pengolahan limbah padat yang sekaligus memanfaatkannya menjadi produk lain, dengan demikian limbah padat yang dihasilkan menjadi suatu permasalahan bagi industri pengolahan rumput laut. Beberapa perusahaan pengolahan rumput laut di Indonesia menggunakan area lahan yang luas untuk membuang limbah padat yang dihasilkan.

*) Peneliti pada Balai Besar Riset Pengolahan Produk dan Bioteknologi Kelautan dan Perikanan, DKP 
Berdasarkan karakterisasi limbah diketahui bahwa limbah pengolahan rumput laut terdiri dari dua fase yakni fase cair dan fase padat. Fase cair berasal dari pencucian dan presipitasi ekstraksi rumput laut, sedangkan fase padat berasal dari pemisahan ekstrak rumput laut dari padatannya. Komposisi utama fase padat adalah selulosa, sedangkan komponen lainnya adalah mineral-mineral. Kadar air fase padat dapat mencapai $68,4 \%$, kadar abu $31 \%$, dan kadar serat 20,1\% (Basmal et al., 2003). Kandungan selulosa yang tinggi pada limbah padat pengolahan rumput laut ini dijadikan dasar dalam penelitian untuk memanfaatkannya menjadi bahan pembuatan papan partikel. Papan partikel adalah salah satu jenis panil kayu yang terbuat dari partikel-partikel kayu atau bahan berlignoselulosa lainnya yang dicampur dengan perekat sintetis atau bahan pengikat lain kemudian dikempa dengan panas. Dalam pembuatan panil, dapat ditambahkan bahan penolong dengan tujuan untuk memperbaiki sifat-sifat tertentu dari panil tersebut (Maloney, 1977). Keuntungan dari usaha pembuatan papan partikel tidak hanya terletak pada banyaknya macam bahan baku yang dapat digunakan, akan tetapi juga pada cara pembuatan dan sifat papan partikel yang dapat diberikan. Papan partikel mudah dikerjakan (dipotong, dipaku, dan lainlain) sehingga mudah untuk memenuhi persyaratan yang diperlukan dalam pemakaian (Sulastiningsih et al., 1999). Tuntutan pasar yang berkembang saat ini yaitu semakin gencarnya penolakan produk kayu olahan yang berbahan baku kayu dari hutan alam tropis (Prasetya et al., 2006). Dengan semakin langkanya bahan baku kayu untuk industri perkayuan, akhir-akhir ini berkembang kecenderungan untuk memanfaatkan bahan-bahan lain sebagai alternatif dari kayu, misalnya limbah dari kegiatan pertanian (Xu et al., 2004)

Perekat adalah suatu bahan yang mempunyai kemampuan untuk menggabungkan material melalui ikatan permukaan (Houwink \& Solomon, 1965). Perekat yang selama ini digunakan dalam pembuatan papan partikel adalah perekat sintetis antara lain urea formaldehid, fenol formaldehid, dan melamin formaldehid. Perekat tersebut berbahan baku minyak bumi yang persediaannya semakin berkurang dan bersifat tidak dapat diperbarui, oleh karena itu bahan perekat yang digunakan pada penelitian ini adalah jenis polimer polietilen. Polietilen merupakan jenis plastik yang umum digunakan oleh masyarakat, sehingga plastik tersebut dapat diperoleh dengan mudah. Selain itu penggunaan polimer polietilen sebagai bahan perekat dalam pembuatan papan partikel memberikan hasil yang lebih baik dibandingkan dengan menggunakan polimer plastik lainnya yang juga umum digunakan oleh masyarakat yaitu polipropilen (PP) dan polistiren (PS) (Massijaya et al., 2000).

Polietilen tergolong ke dalam perekat termoplastik yang bersifat hidrofobik sehingga penggunaannya sebagai perekat dapat menghasilkan produk yang lebih baik. Termoplastik adalah perekat yang akan menjadi lunak bila diberi panas dan akan mengeras kembali bila panasnya dihilangkan sehingga reaksinya dapat bolak-balik (Ruhendi, 1988). Proses pengempaan dalam pembuatan papan partikel merupakan proses utama yang akan menentukan sifat fisik dan mekanik dari produk yang akan dihasilkan. Pengempaan dapat dilakukan pada suhu ruang (pengempaan dingin) atau dengan pengempaan panas, hal ini sangat terkait dengan jenis bahan pengikat yang berfungsi untuk melekatkan partikelpartikel kayu atau serat yang digunakan.

Penelitian ini ditujukan untuk membuat papan partikel berbahan dasar limbah padat pengolahan Gracilaria sp. Produk ini memiliki pemakaian yang sangat luas, baik sebagai bahan bangunan pengganti papan kayu maupun sebagai aksesori rumah tangga. Salah satu keunggulan dari selulosa adalah mempunyai sifat menolak air, sehingga panel yang dibuat akan memiliki sifat yang tahan air. Produkproduk komposit untuk bahan bangunan yang mempunyai sifat tahan air sangat diminati saat ini, khususnya di negara-negara tropis dan lembab. Dengan demikian, limbah padat hasil pengolahan rumput laut sebagai bahan dasar pembuatan papan partikel dapat menjadi salah satu solusi mengatasi permasalahan pembuangan limbah industri pengolahan rumput laut, dan juga dapat mengatasi permasalahan yang berkaitan dengan lingkungan dan pencemarannya.

\section{BAHAN DAN METODE}

Bahan yang digunakan dalam penelitian ini adalah limbah padat pengolahan rumput laut Gracilaria sp. yang berasal dari PT. Agarindo Bogatama, Pasar Kemis, Banten. Sampel limbah padat diambil langsung di tempat pembuangan limbah dan dimasukkan ke dalam karung goni untuk dibawa ke laboratorium. Bahan lain yang digunakan adalah plastik polietilen dan aluminium foil.

Teknik pembuatan papan partikel yang digunakan yaitu dengan pengepresan panas dengan tekanan tinggi. Limbah padat dari industri pengolahan agar dikeringkan di bawah matahari hingga kadar air $\pm 5 \%$, kemudian limbah tersebut digiling dan diayak dengan ukuran 26 mesh. Limbah yang telah diayak dicampur dengan bahan pengikat polietilen dengan perbandingan 1:1 (w/w), kemudian dihomogenkan dengan alat cone-homogenizer yang dikembangkan 
oleh Balai Besar Riset Pengolahan Produk dan Bioteknologi Kelautan dan Perikanan (Basmal et al., 2006). Setelah itu campuran dimasukkan ke dalam cetakan plat tembaga dengan ukuran $30 \times 30 \times 2,5$ $\mathrm{cm}^{3}$. Lapisan bawah dan atas dari campuran bahan baku dialasi dengan aluminium foil, kemudian setelah dipanaskan mencapai suhu $150^{\circ} \mathrm{C}$ dilakukan pengepresan dengan tekanan $10 \mathrm{~kg} / \mathrm{cm}^{2}$ pada suhu konstan $150^{\circ} \mathrm{C}$ dengan variasi lama pengempaan 3 , 5 , dan 7 menit. Alat pengepres yang digunakan merupakan pengepres sistem hidrolik manual, dengan plat pengepres yang dilengkapi pemanas listrik yang dihubungkan dengan thermostat untuk pengaturan suhu plat pengepres.

Setelah pengepresan, papan partikel masih dalam kondisi sangat panas dan lunak. Papan partikel dibiarkan selama 3 jam sampai dingin (suhu ruang) dan mengeras setelah itu baru dikeluarkan dari cetakan. Papan partikel yang dihasilkan dikondisikan selama satu minggu pada suhu ruang. Papan partikel tersebut diuji sifat fisik dan mekanisnya serta uji ketahanan terhadap rayap. Alur proses pembuatan papan partikel dapat dilihat pada Gambar 1.

Analisis sifat fisik papan partikel meliputi kerapatan, kadar air, daya serap air, dan pengembangan tebal (JIS A 5908, 1994). Pengujian mekanik papan partikel meliputi keteguhan patah, keteguhan lentur, dan keteguhan rekat internal (JIS A $5908,1994)$. Pengujian terhadap rayap kayu kering dikerjakan sesuai prosedur Hadi \& Febrianto (1991). Ulangan pada penelitian ini dilakukan sebanyak tiga kali.

\section{HASIL DAN BAHASAN}

\section{Sifat Fisik}

\section{Kerapatan}

Kerapatan bahan baku merupakan salah satu faktor yang mempengaruhi kualitas dari produk papan partikel yang dihasilkan. Kerapatan yang dihasilkan dari ketiga perlakuan papan partikel berdasarkan lama waktu pengempaan berada dalam standar JIS A 5908, 1994 yang menetapkan besarnya kerapatan untuk papan partikel jenis waferboard sebesar 0,4-0,9 g/ $\mathrm{cm}^{3}$. Sedangkan papan partikel yang dihasilkan memiliki kerapatan 0,82-0,87 g/ $/ \mathrm{cm}^{3}$ (Gambar 2).

Lama pengempaan dengan waktu 3, 5, dan 7 menit tidak memberikan pengaruh yang berbeda nyata terhadap kerapatan papan partikel yang dihasilkan. Menurut Kelly (1977), besarnya kerapatan papan partikel dipengaruhi oleh kerapatan bahan awal, kandungan perekat serta bahan aditif yang digunakan. Kerapatan papan partikel yang dihasilkan pada penelitian ini lebih tergantung kepada distribusi partikel dalam papan (limbah padat dan polietilen). Karena papan partikel dibuat dengan bahan dasar dan

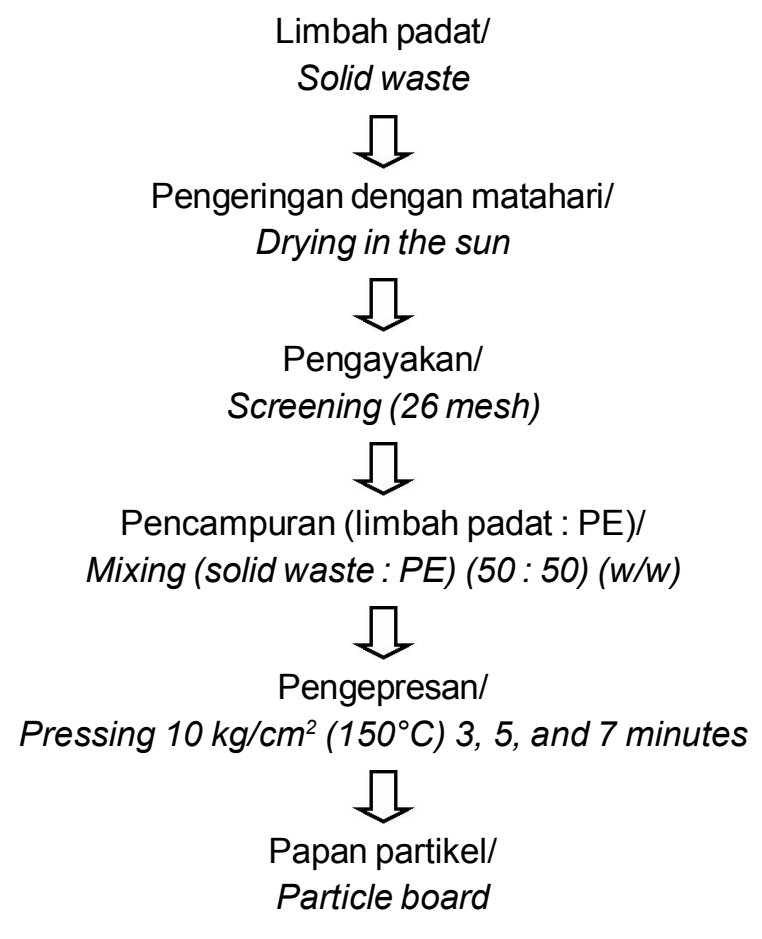

Gambar 1. Alur proses pembuatan papan partikel. Figure 1. Flow chart of particle board processing. 


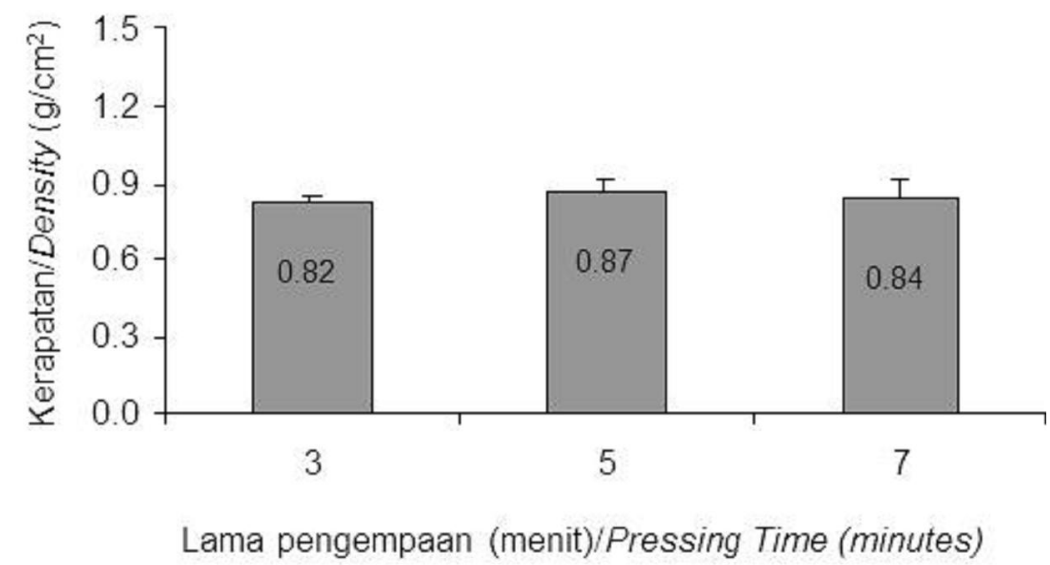

Gambar 2. Hubungan lama pengempaan dengan kerapatan papan partikel.

Figure 2. Correlation between pressing time and density of particle board.

dengan perbandingan yang sama, maka lama pengempaan tidak memberikan pengaruh yang nyata terhadap kerapatan papan partikel yang dihasilkan. Penghomogenan yang baik sebelum campuran dimasukkan ke dalam cetakan dapat menghasilkan kerapatan papan partikel yang baik.

\section{Kadar air}

Kadar air merupakan sifat fisik papan partikel yang menunjukkan kandungan air papan dalam keadaan setimbang dengan lingkungan sekitarnya terutama kelembaban udara. JIS A 5908, 1994 menetapkan nilai kadar air untuk papan partikel jenis waferboard antara $5-13 \%$. Hasil pengujian kadar air papan partikel dari ketiga papan yang dihasilkan menunjukkan nilai yang lebih rendah dari standar yang telah ditentukan. Kadar air dari ketiga papan partikel berkisar antara 2,43$3,92 \%$ (Gambar 3).
Kadar air dari ketiga papan partikel yang dihasilkan sangat rendah disebabkan karena ukuran partikel dari bahan limbah padat pengolahan agar yang digunakan sangat halus dan juga tingginya campuran plastik (PE) yang terkandung dalam bahan sehingga papan yang dihasilkan bersifat hidrofobik. Salah satu sifat plastik yang khas adalah tidak terdapatnya air dalam susunan kimiawinya atau dapat dikatakan juga kadar air plastik sama dengan nol, kemudian dengan ukuran dan keseragaman partikel bahan baku awal, serta ukuran yang lebih kecil dengan keseragaman (homogenasi) yang tinggi berakibat kecilnya pori-pori dari papan partikel yang dihasilkan, hal ini menyebabkan air di lingkungan sulit untuk mempenetrasi ke dalam papan. Berdasarkan hasil analisis, kadar air tertinggi adalah pada lama pengempaan 5 menit, sedangkan kadar air terendah adalah pada lama pengempaan 3 menit.

Waktu dan kondisi pengempaan mempengaruhi kadar air dan sifat fisik dari papan partikel, waktu

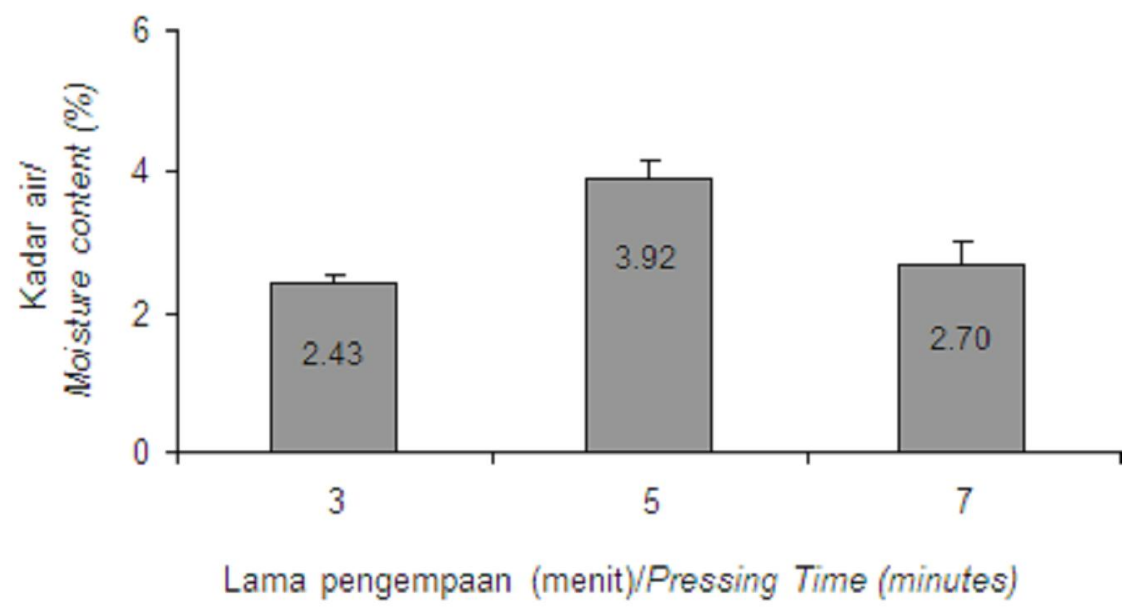

Gambar 3. Hubungan lama pengempaan dengan kadar air papan partikel.

Figure 3. Correlation between pressing time and moisture content of particle board. 
pengempaan dan suhu berpengaruh terhadap proses pematangan perekat. Hal ini berkorelasi dengan waktu kempa total yang diperlukan dan gradien kerapatan vertikal papan (Kelly, 1977).

\section{Daya serap air}

Salah satu karakteristik komposit yang paling penting adalah sifat-sifat yang berkaitan dengan stabilitas dimensi dan penyerapan air, analisis yang dilakukan antara lain: daya serap air, pengembangan tebal, dan pengembangan linear. Daya serap air merupakan sifat fisik yang mencerminkan kemampuan papan partikel untuk menyerap air setelah papan direndam di dalam air selama 24 jam, daya serap air adalah faktor utama yang mempengaruhi sifat pengembangan tebal papan partikel yang dihasilkan.

Hasil pengujian terhadap daya serap air menunjukkan bahwa penyerapan air dari ketiga papan partikel dari perlakuan yang berbeda berkisar antara 7,71-18,13\% (Gambar 4). Daya serap air terendah dimiliki oleh papan partikel dengan lama pengempaan 7 menit yaitu $7,71 \%$ dan tertinggi pada papan partikel dengan lama pengempaan 5 menit yaitu 18,13\%.

Berdasarkan data di atas, daya serap air dari papan partikel yang dihasilkan berkorelasi kuat dengan tingkat kerapatannya. Kerapatan papan partikel yang tinggi akan menyebabkan rendahnya daya serap air, demikian pula sebaliknya. Menurut penelitian Nugroho \& Ando (2000), penurunan penyerapan air dengan meningkatnya kerapatan papan disebabkan karena pada papan kerapatan tinggi rongga-rongga antar partikel (voids) lebih sedikit dibandingkan papan partikel kerapatan rendah. Hal ini akan mengurangi penetrasi air ke dalam papan partikel.

Penurunan penyerapan air dapat terjadi karena waktu pengempaan yang lebih lama, yang berdampak pada berkurangnya sifat higroskopis bahan akibat terjadinya degradasi komponen utama dinding sel selama proses pengempaan panas (Schneider et al., 1996).

\section{Pengembangan tebal}

Sifat pengembangan tebal merupakan sifat fisik yang akan menentukan apakah suatu papan partikel dapat digunakan untuk suatu keperluan eksterior atau interior. Bila pengembangan tebal tinggi, maka stabilitas dimensi papan rendah sehingga tidak dapat digunakan untuk penggunaan eksterior pada jangka waktu yang lama karena sifat mekanis yang dimilikinya segera menurun secara drastis dalam waktu yang tidak lama.

Hasil analisis terhadap pengembangan tebal papan patikel yang dihasilkan berkisar antara 0,00-3,42\% (Gambar 5). Nilai pengembangan tebal terendah yaitu pada lama pengempaan 3 menit, sedangkan pengembangan tebal tertinggi pada papan partikel dengan lama pengempaan 5 menit. Faktor terpenting yang mempengaruhi pengembangan tebal papan partikel adalah kerapatan kayu atau bahan pembentuknya. Papan partikel yang dibuat dari kayu atau bahan yang berkerapatan rendah akan mengalami pengempaan yang lebih besar pada saat pembuatan sehingga bila direndam dalam air akan mengalami pembebasan tekanan yang lebih besar yang mengakibatkan pengembangan tebal menjadi lebih tinggi (Halligan, 1970 dalam Rosid, 1995).

Campuran bahan papan partikel menggunakan limbah padat rumput laut dengan bahan pengikat polietilen memiliki tingkat kerapatan yang tinggi karena bahan awal berupa serbuk yang cukup halus, sehingga tingkat pembebasan tekanan selama perendaman menjadi rendah. Pengembangan tebal

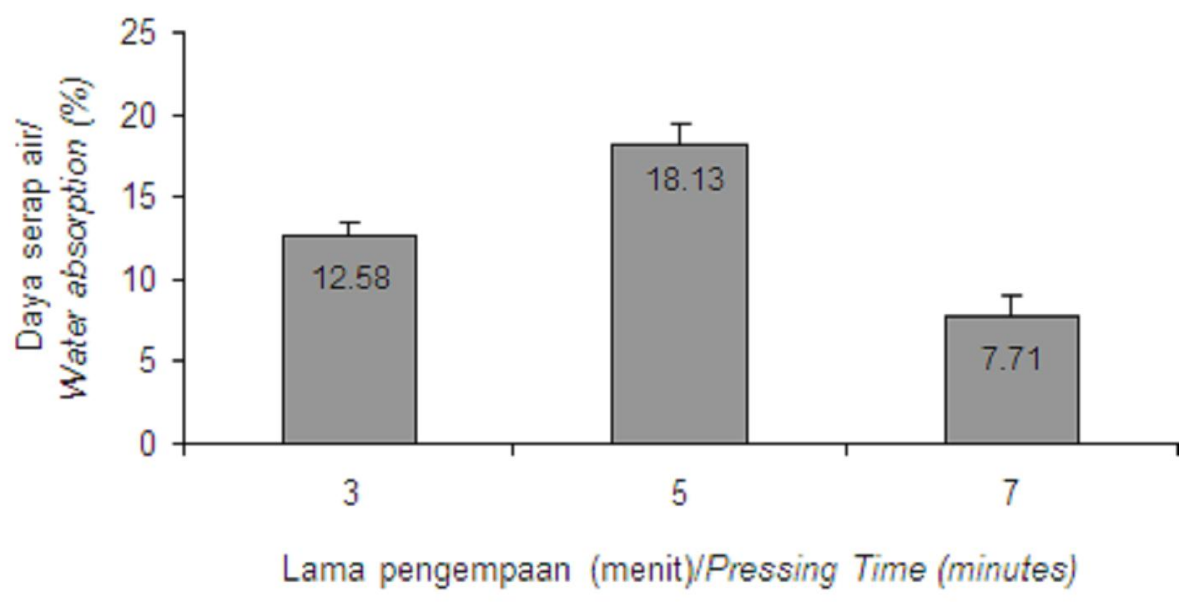

Gambar 4. Hubungan lama pengempaan dengan daya serap air papan partikel.

Figure 4. Correlation between pressing time and water absorption of particle board. 


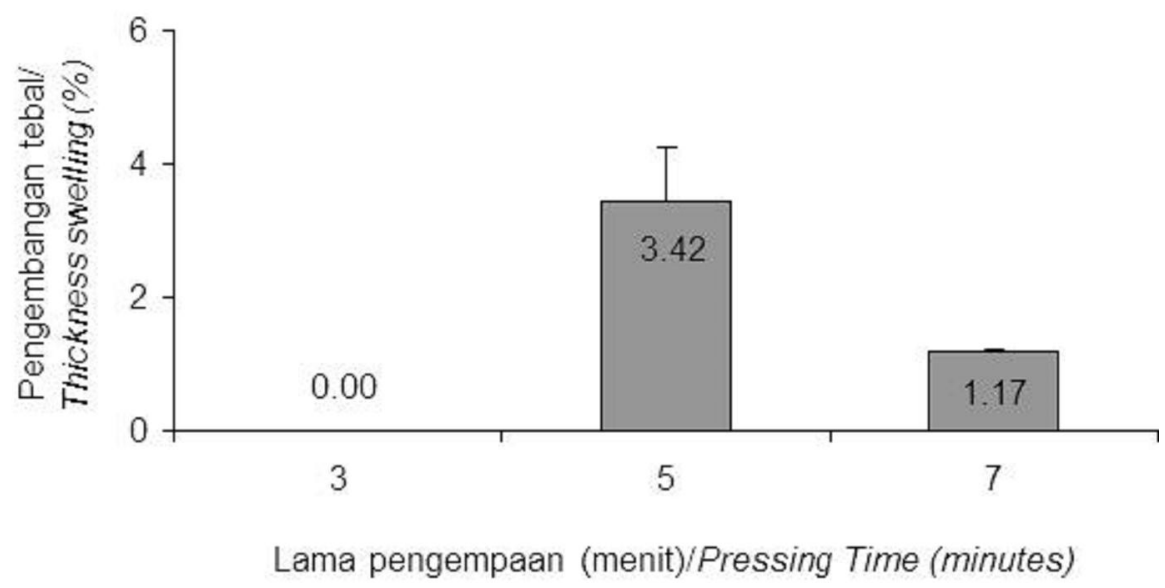

Gambar 5. Hubungan lama pengempaan dengan pengembangan tebal papan partikel.

Figure 5. Correlation between pressing time and thickness swelling properties of particle board.

papan partikel sejalan dengan kerapatan papan partikel karena pengembangan tebal disebabkan oleh tambahan volume air yang terserap masuk ke dalam jaringan mikrofibril dari bahan partikel (Prayitno \& Gentur, 1989). Berdasarkan hasil pengembangan tebal dari papan partikel yang dihasilkan, didapatkan bahwa seluruh papan partikel yang dihasilkan telah memenuhi standar mutu JIS A 5908 yang mensyaratkan standar pengembangan tebal maksimal $12 \%$.

\section{Keteguhan patah (Modulus of Rupture/MOR) dan keteguhan lentur (Modulus of Elasticityl MOE)}

Keteguhan patah (MOR) merupakan sifat mekanis kayu yang menunjukkan kekuatan kayu dalam menahan beban, sedangkan keteguhan lentur (MOE) merupakan ukuran ketahanan papan partikel untuk menahan beban dalam batas proporsi (sebelum patah)
(Massijaya et al., 1999). Sifat ini sangat penting jika papan partikel digunakan sebagai bahan konstruksi. Nilai keteguhan patah (MOR) dan keteguhan lentur (MOE) papan partikel yang dihasilkan yaitu berkisar $58,88-96,78 \mathrm{~kg} / \mathrm{cm}^{2}$ dan $2.425-6.326 \mathrm{~kg} / \mathrm{cm}^{2}$ (Gambar 6 dan 7).

Lama pengempaan mempengaruhi tingkat kematangan pada produk akhir. Waktu pengempaan yang terlalu singkat akan menyebabkan perekat kurang matang, sehingga perekat tidak cukup kuat untuk mengikat partikel bahan. Sebaliknya, jika suhu kempa terlalu tinggi dan waktunya lama, akan mengakibatkan perekat terlalu matang sehingga kekuatan rekat kurang baik.

Berdasarkan grafik pada Gambar 6 dan 7, terlihat bahwa nilai MOR dan MOE papan partikel meningkat seiring dengan lamanya waktu pengempaan. Hal ini berkaitan dengan tingkat kematangan bahan pengisi polietilen selama pengempaan, plastik polietilen lebih

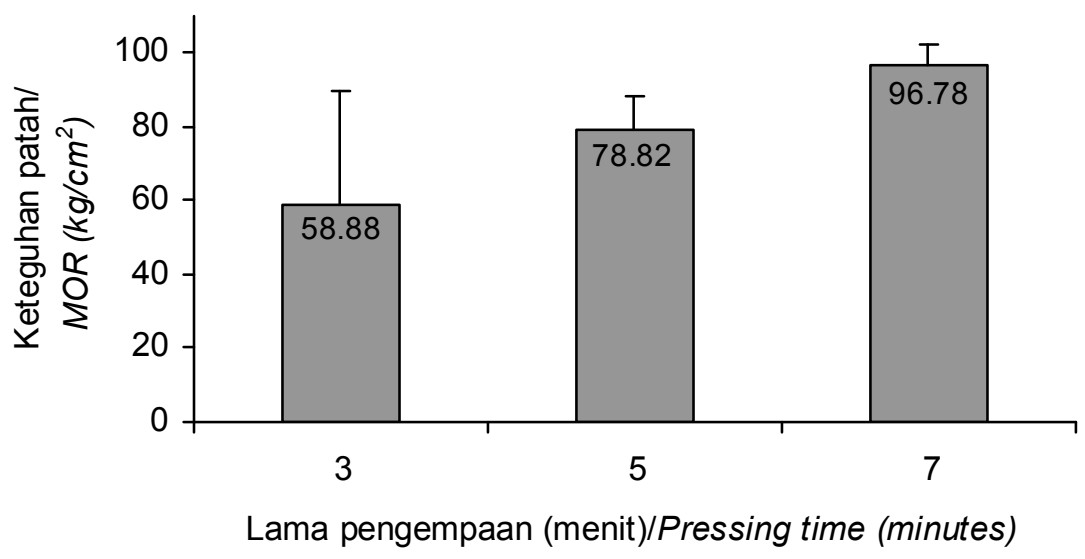

Gambar 6. Hubungan lama pengempaan dengan keteguhan patah papan partikel.

Figure 6. Correlation between pressing time and the modulus of rupture (MOR) properties of particle board. 


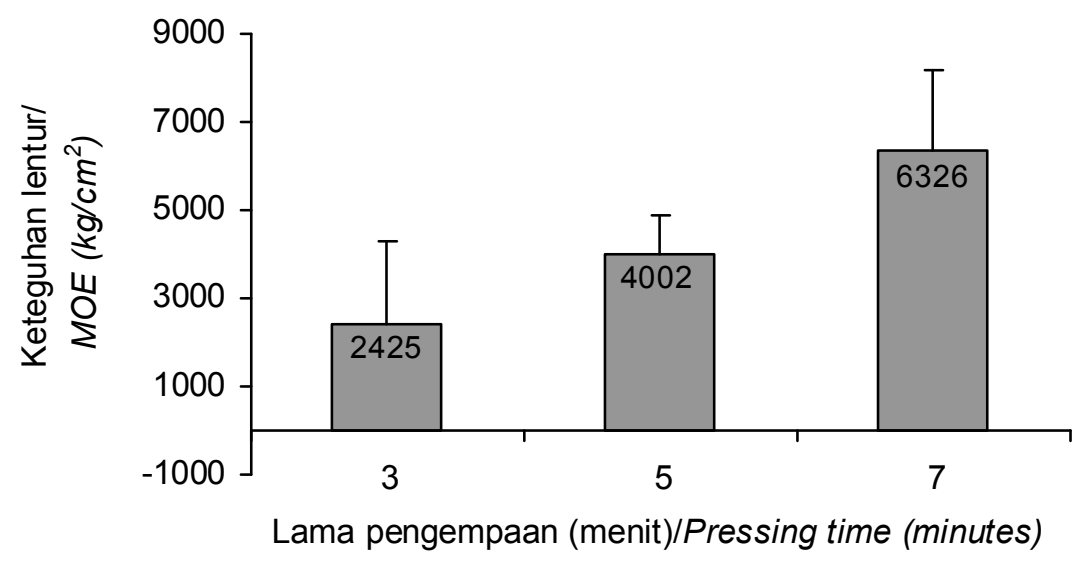

Gambar 7. Hubungan lama pengempaan dengan keteguhan lentur papan partikel.

Figure 7. Correlation between pressing time and the modulus of elasticity (MOE) of particle board.

memiliki peran terhadap nilai MOR dan MOE dari papan partikel yang dihasilkan. Waktu pengempaan yang lebih panjang hingga 7 menit menghasilkan tingkat kematangan polietilen yang lebih baik terhadap papan partikel yang dihasilkan, sehingga menghasilkan nilai MOR dan MOE yang lebih tinggi.

JIS A 5908 mensyaratkan nilai keteguhan patah minimal $82 \mathrm{~kg} / \mathrm{cm}^{2}$ dan nilai minimal keteguhan lentur sebesar $20.400 \mathrm{~kg} / \mathrm{cm}^{2}$, sedangkan hasil percobaan menunjukkan, nilai MOR dan MOE papan partikel dengan lama pengempaan di bawah 7 menit masih lebih rendah dibandingkan dengan nilai yang disyaratkan. Hal ini diduga karena belum cukupnya waktu pengempaan untuk mematangkan campuran bahan papan partikel secara sempurna, juga diduga tidak terjadinya ikatan spesifik antara partikel limbah rumput laut dengan partikel plastik (Perlson \& Schababerle, 1992).

\section{Keteguhan rekat (Internal Bond)}

Keteguhan rekat (internal bond) merupakan ukuran tunggal terbaik tentang kualitas pembuatan suatu papan karena menunjukkan kekuatan ikatan antara partikel-partikel. Keteguhan rekat adalah suatu uji pengendalian kualitas pencampuran, pembentukan, dan proses pengempaan. Nilai keteguhan rekat papan partikel yang dihasilkan yaitu berkisar antara 6,41$7,39 \mathrm{~kg} / \mathrm{cm}^{2}$, nilai keteguhan rekat papan partikel tertinggi diperoleh pada lama pengempaan 3 menit dan terendah pada lama pengempaan 5 menit (Gambar 8). Nilai keteguhan rekat papan partikel yang dihasilkan seluruhnya memenuhi nilai standar JIS A 5908 yang mensyaratkan nilai keteguhan rekat untuk papan partikel minimal $2 \mathrm{~kg} / \mathrm{cm}^{2}$.

Kekuatan rekat dipengaruhi oleh partikel kayu, kadar air partikel, perekat, kondisi pengempaan, dan

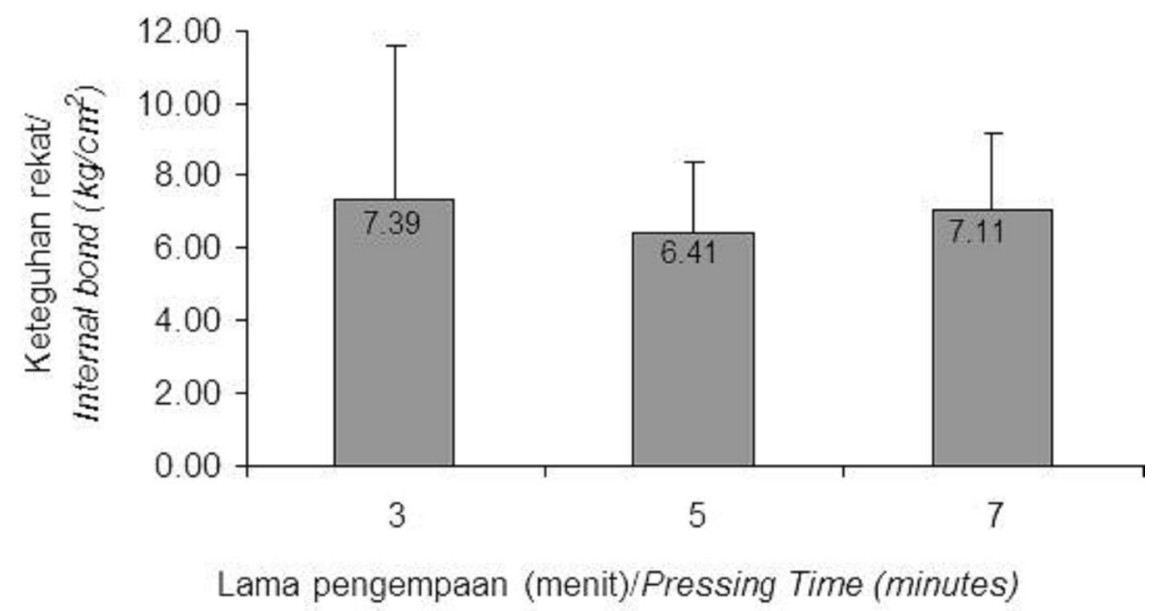

Gambar 8. Hubungan lama pengempaan dengan keteguhan rekat papan partikel.

Figure 8. Correlation of pressing time periods to the internal bond of particle board. 
penambahan bahan pengawet. Lama pengempaan akan mempengaruhi tingkat kematangan pada produk akhir. Waktu pengempaan yang terlalu singkat akan menyebabkan perekat kurang matang, sehingga perekat tidak cukup kuat untuk mengikat partikel bahan. Sebaliknya, jika suhu kempa terlalu tinggi dan waktunya lama, akan mengakibatkan perekat terlalu matang sehingga kekuatan rekat kurang baik.

Kekuatan papan partikel pada dasarnya ditentukan oleh kekuatan ikatan antar partikel dan kekuatan masing-masing partikel itu sendiri. Pemakaian partikel halus akan meningkatkan luas areal permukaan per satuan berat yang menyebabkan penggunaan perekat menjadi kurang efisien, di samping lebih banyaknya individu-individu serat yang mengalami kerusakan, sehingga akan menghasilkan lembaran dengan kekuatan yang rendah serta merosotnya stabilitas dimensi (Lehman, 1974 dalam Kusmayadi, 2001).

\section{Uji ketahanan terhadap rayap}

Parameter ketahanan terhadap serangan rayap juga merupakan hal yang berpengaruh terhadap kualitas papan partikel yang dihasilkan, karena aplikasi pemanfaatan papan partikel khususnya untuk keperluan rumah tangga dan konstruksi bangunan sangat rentan terhadap serangan rayap. Nilai ketahanan terhadap rayap dari papan partikel yang dihasilkan yaitu berkisar antara 1,55-6,79\% (Gambar 9).

Berdasarkan pengamatan, dapat diketahui bahwa uji ketahanan terhadap rayap papan partikel berkorelasi erat dengan tingkat kerapatan papan partikel yang dihasilkan, yaitu semakin tinggi kerapatannya maka papan partikel memiliki sifat fisik kekerasan yang semakin tinggi, sehingga ketahanan terhadap rayap menjadi lebih tinggi pula. Pada perlakuan lama pengempaan 3 dan 7 menit didapatkan nilai derajat proteksi papan partikel utuh atau tidak terserang $(<5 \%)$, sedangkan untuk papan partikel dengan lama pengempaan 5 menit memiliki nilai derajat proteksi papan partikel terserang sedikit $(6-15 \%)$ (Hadi \& Febrianto, 1991).

\section{KESIMPULAN}

Berdasarkan hasil uji papan partikel yang berbahan dasar limbah padat pengolahan rumput laut dan polietilen, diketahui bahwa sifat mekanis untuk nilai keteguhan patah (MOR) dan keteguhan lentur (MOE) papan partikel yang dihasilkan masih berada di bawah standar JIS A 5908, namun nilai keteguhan rekatnya (internal bond), sebagai ukuran tunggal terbaik tentang kualitas pembuatan suatu papan partikel sudah memenuhi standar JIS A 5908. Berdasarkan sifat fisik papan partikel yang dihasilkan dari ketiga perlakuan yaitu kerapatan, kadar air, dan pengembangan tebal terlihat bahwa papan partikel secara keseluruhan telah memenuhi standar JISA 5908. Perlakuan pengempaan 3 menit merupakan perlakuan terbaik berdasarkan sifat fisik pengembangan tebal serta sifat mekanik keteguhan rekat (internal bond) dibandingkan perlakuan pengempaan 5 dan 7 menit.

Berdasarkan hasil penelitian dapat diketahui bahwa limbah padat pengolahan rumput laut memiliki potensi yang baik untuk dijadikan sebagai bahan baku pembuatan papan partikel.

\section{DAFTAR PUSTAKA}

Basmal, J., Yeni, Y., Murdinah, Suherman, M., dan Gunawan, B. 2003. Laporan Teknis Pusat Riset Pengolahan Produk dan Sosial Ekonomi Kelautan dan Perikanan. Badan Riset Kelautan dan Perikanan

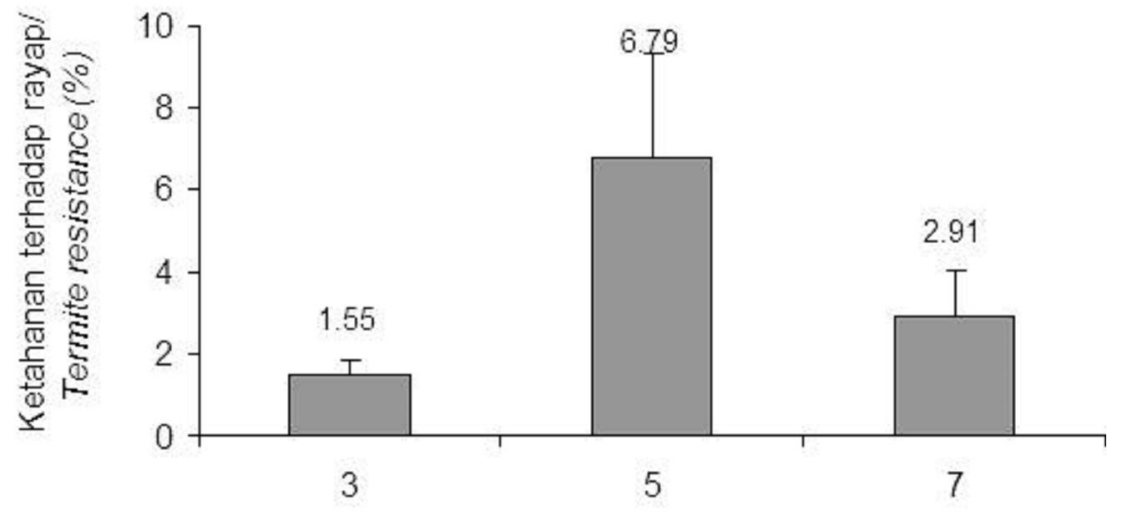

Lama pengempaan (menit)/Pressing Time (minutes)

Gambar 9. Hubungan lama pengempaan dengan ketahanan papan partikel terhadap rayap.

Figure 9. Correlation between pressing time and termite resistance of particle board. 
- Departemen Kelautan dan Perikanan, Jakarta. $61 \mathrm{pp}$

Basmal, J., Utomo, B.S.B., Fithriani, D., dan Sedayu, B.B. 2006. Riset rekayasa alat daur ulang limbah padat dan cair pengolahan rumput laut. Laporan Teknis. Balai Besar Riset Pengolahan Produk dan Bioteknologi Kelautan dan Perikanan, Jakarta. p. 1-30.

JIS A 5908. 1994. Japanese Industrial Standard Particleboard. Japanese Standars Association, Japan.

Hadi, Y.S. dan Febrianto, F. 1991. Daya tahan papan partikel rendaman panas dan asetilasi terhadap serangan rayap kering Cryptotermes cynocephalus Light. Teknologi, Buletin Jurusan Teknologi Hasil Hutan. Fahutan IPB. IV(1): 23-29.

Houwink and Solomon. 1965. Adhesion and Adhesive. Elsevier Publishing Company, New York.

Kelly, M.W. 1977. Critical Literature Review of Relationship between Processing Parameters and Physical Properties of Particle-board. USDA for. Serv. Gen. Tech. Rep. FPL-10. Madison, WI: USDA, Forest Service, Forest Product Laboratory. 66 pp.

Kusmayadi. 2001. Pengaruh Rasio Kompresi (Compaction Ratio) Terhadap Sifat Fisis dan Mekanis Papan Partikel Beberapa Jenis kayu. Skripsi. Jurusan Teknologi Hasil Hutan, Fakultas Kehutanan IPB, Bogor.

Maloney, T.M. 1977. Modern Particleboard and Dry Process Fiberboard Manufacturing. Miller Fremann, Inc., San Fransisco.

Massijaya, M.Y., Hadi, Y.S., Tambunan B., Bakar B.S., dan Subari W.A. 2000. Penggunaan limbah plastik sebagai komponen bahan baku papan partikel.
Jurnal Teknologi Hasil Hutan. Fakultas Kehutanan IPB. XIII(2): 18-24.

Nugroho N. and Ando, N. 2000. Development of structural composite product made from bamboo I: Fundamental properties of bamboo zephyr board. J. Wood Science. 46: 68-74.

Perlson, B.D. and Schababerle, C.C. 1992. Polyolefins. Plastic Recycling, Products, and Process. Hansher Publishers, Germany.

Prasetya B., Sudijono, dan Kasinoputro, P. 2006. Pemanfaatan lumpur minyak untuk pembuatan komposit berserat lignoselulosa. J. Tropical Wood Science and Technology. 4(1): 9-14.

Prayitno, T.A. dan Gentur, J.P. 1989. Sifat papan partikel kayu mangium, sengon dan karet. Proceeding Diskusi Sifat dan Kegunaan Jenis Kayu HTI. Badan Litbang Kehutanan, Departemen Kehutanan, Jakarta

Rosid IK. 1995. Sifat-Sifat Papan Partikel Menggunakan Perekat Lateks Polistiren Kopolimer. Fakultas Kehutanan, Institut Pertanian Bogor.

Ruhendi, S. 1988. Teknologi Perekatan. Pusat Antar Universitas Bioteknologi, IPB, Bogor

Schneider, M.H., Chui, C.Y., and Ganev, S.B. 1996. Properties of particle-board made with polyfurfuryl L-alcohol/Urea formaldehyde adhesive. Forest Product Journal. 46: 79-83.

Sulastinigsih, I.M., Jasni, dan Iskandar, M.I. 1999. Pengaruh permetrin terhadap sifat fisis, mekanis, dan keawetan papan partikel. Buletin Penelitian Hasil Hutan. 16(4): 219-229.

Xu, X., Zhu D., Wu Q., and Vlosky, R.P. 2004. Agro-based composite in China: opportunities and challenges. Forest Products Journal. 54(5): 8-15. 
